\title{
Concretising the role of extended producer responsibility in European Union waste law and policy through the lens of the circular economy
}

\author{
Kleoniki Pouikli ${ }^{1,2}$ \\ Published online: 10 February 2020 \\ (C) The Author(s) 2020

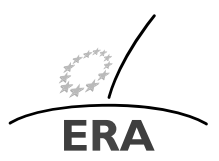 \\ EUROPÄISCHE RECHTSAKADEMIE \\ ACADEMY OF EUROPEAN LAW \\ ACADEMIE DE DROIT EUROPEEN \\ ACCADEMIA DI DIRITTO EUROPEO \\ TRIER - TREVES - TREVIRI
}

\begin{abstract}
The aim of this paper is to shed light on the main aspects of Extended Producer Responsibility (EPR), a widely used principle of environmental policy, looking through the lens of EU waste law and policy, as this is currently evolving. The main discussion will revolve around the opportunities of moving towards a more effective EPR and adopting more effective policy instruments. Emphasis will be given to the definition of EPR, to its content and to implementation schemes in EU law especially as regards the role of EPR in achieving the challenging targets which exist relating to waste management and product design requirements under the Circular Economy Package, while at the same time highlighting the inter-relationship between waste and product laws.
\end{abstract}

Keywords Extended producer responsibility · EU waste law · Circular economy · Waste hierarchy

\section{Introduction}

Waste generation constitutes the key by-product of modern economic and social lifestyle and consumption patterns and one of the main - and constantly worseningproblems for the environment and human health, despite all attempts to control it. ${ }^{1}$ More specifically, in 2014, 2598 million tons of waste were generated by all economic activities and households in the 28 EU Member States, equating to more than

\footnotetext{
${ }^{1}$ Steenmans K., Malcolm R., Marriott J., [11], p. 2.

$凶$ Dr. K. Pouikli

Kpouikli@era.int

1 Course Director in Environmental Law, ERA Academy of European Law, Trier, Germany

2 Post-Doctoral Researcher, National and Kapodestrian University of Athens, Athens, Greece
} 
$5118 \mathrm{~kg}$ per EU inhabitant. ${ }^{2}$ Apart from the environmental and health impacts, waste is directly related to economic loss, as it is estimated that materials sent to landfill in the EU could have a commercial value of around $€ 5.25$ billion per annum. ${ }^{3}$ In addition to this, what should be taken into account is the cost of infrastructure required for the collection, sorting and management of waste as well as the resource crisis due to the over-exploitation of natural resources caused by population growth, urbanisation, unsustainable economic activities and consumption patterns.

To address the pressing challenges in this field, the EU decided to transform its linear economy (involving take-make-dispose) into a Circular Economy, ${ }^{4}$ thus aspiring to decouple economic growth and well-being from ever-increasing waste generation, strengthen environmentally sound waste management, enhance eco-design, achieve higher recycling rates and reduction of waste, stimulate competitiveness and resource-efficiency as well as create new jobs and opportunities for new businesses, innovations and investments by keeping the added value in products for as long as possible in the market. The Circular Economy policy highlights in a holistic way the inter-relationship between resource, substance, product and waste, highlighting the interactions between waste, product and chemical laws, and taking into consideration the fact that waste-other than pollution — can be conceived of as a raw material and used as such in a production process. The life-cycle thinking incorporated in the Circular Economy concept stresses the need to take into account the environmental impacts of an entire material life-cycle in an integrated way.

The fact that the Circular Economy has put the spotlight on the life-cycle perspective constitutes a clear sign of the building of interlinkages among legally binding product standards, resource and waste law and policy, and legislation on chemicals, given that the decisions made in the period when a product is conceptualised and manufactured by industry (design stage) are extremely important for all the stages of its lifetime. In the field of waste law and policy, the main concerns revolve around the obstacles and challenges related to "environmentally sound waste management", since according to the Circular Economy Action Plan only around $40 \%$ of the waste generated by EU households is currently recycled whereas, in 2013, the total waste generation in the EU amounted to approximately 2.5 billion tons of which 1.6 billion tons were not used or recycled. ${ }^{5}$ The Circular Economy Package calls, in particular, for further clarification of the definition of waste as well as for a better application of the waste hierarchy with emphasis being put on increasing both the quantity and the quality of recycling.

To this end, the Extended Producer Responsibility (EPR) principle has emerged as a significant tool which fosters the enforcement of the Circular Economy Package requirements in the field of EU waste law and policy and at the same time functions as a connective tissue between the different relevant legislative and policy fields. Briefly,

\footnotetext{
${ }^{2}$ Eurostat, Waste Statistics, December 2016.

${ }^{3}$ European Commission, [3].

${ }^{4}$ Communication from the Commission to the European Parliament, the Council, the European Economic and Social Committee and the Committee of the Regions Closing the loop-An EU action plan for the Circular Economy, Brussels, 2.12.2015, COM(2015) 614 final.
}

${ }^{5}$ Ibid., pp. 8-9. 
EPR is a financial and/or operational instrument which has a double key aim: internalising environmental externalities related to end-of-life management and fostering the operational implementation of sustainable product and waste management schemes in line with the waste hierarchy and with qualitative recycling and recovery targets. ${ }^{6}$ It therefore focuses on shifting responsibility upstream to the producer away from municipalities as well as on giving incentives to producers to incorporate environmental considerations in the design of their products. ${ }^{7}$

On the basis of this definition, it is obvious that EPR is extremely relevant to the Circular Economy policy, seeking to contribute to sustainable materials management, facilitate recycling and promote design for environment, which will lead to the reduction of the environmental impact of a product generated over its lifetime. In this context, the first part of this article attempts to conceptualise the EPR principle, unpacking its genesis, its development and its content together with its main objectives and policy instruments. The second and third part of the article will shed light on the legal and policy framework for EPR, and on the key elements of already-extant EPR schemes, respectively.

After a brief evaluation of their main positive and negative aspects, the fifth part of the article will be devoted to defining the role of EPR in the context of the Circular Economy with a special focus on plastics. Finally, some concluding remarks will be drawn regarding the opportunities and perspectives of EPR schemes in the framework of the evolving field of waste law and policy.

\section{Conceptualising the EPR principle}

\subsection{Genesis, development and content}

The EPR principle was initially proposed in the framework of management sciences and industrial ecology as a way to improve resource efficiency and as a response to the challenges that many municipalities were facing in managing waste that was growing in volume and complexity. ${ }^{8}$ Therefore, the EPR policy sought to shift from local authorities and taxpayers (i.e., the public budget) to producers the burden of taking responsibility for collecting end-of-life products and for sorting them before their final treatment.

EPR was first introduced as a concept by Thomas Lindhqvist in 2000 and, according to the Organisation for Economic Cooperation and Development (OECD), it is defined as "an environmental policy approach in which a producer's responsibility, physical and/or financial, for a product is extended to the post-consumer stage of a product's life cycle". 9 Thus, producers are deemed liable for such a final phase, as they are the actors best positioned to make the required interventions for reducing the environmental impact of their products.

\footnotetext{
${ }^{6}$ European Commission, [2], pp. 120-121.

${ }^{7}$ OECD, [8], p. 33.

${ }^{8}$ Massarutto A., [7], p. 11.

${ }^{9}$ OECD [9], pp. 18-19.
} 
In European Union law, EPR is considered to be one of the cornerstones of waste policy reflected in different pieces of European Union legislation putting the waste hierarchy into effect by giving incentives to producers to minimise the waste generated and -if waste is generated-to reduce its treatment. ${ }^{10}$ According to Article 4 of the Waste Framework Directive (which lists the different options for managing waste from 'best' to 'worst' from an environmental perspective) the priority order is the following: prevention, (preparing for) re-use, recycling, recovery and, as the least preferred option, disposal (which includes landfilling and incineration without energy recovery). However, the waste hierarchy should not be seen as a rigid prescription, particularly since different waste treatment methods can have different environmental impacts. ${ }^{11}$

It is clear that EPR constitutes a typical second-best policy approach, the essence of which lies in the attempt to correct market failures/imperfections deriving from the breach of the most basic rule of waste law, which provides for the prohibition of the abandonment, dumping or uncontrolled management of waste. The economic rationale behind implementing sound EPR schemes is to have producers internalise treatment and disposal costs so that they have an incentive to design products that last longer and are more easily treated after use. This extension of the producers' responsibility to the post-consumer state of a product's life cycle, incentivises them to take into account environmental considerations providing a basis for effective endof-life collection, for improved reuse and recycling of collected products according to high environmental standards, ${ }^{12}$ for easy-to-disassemble product design, for reduced use of hazardous or toxic substances and for strengthening waste prevention. ${ }^{13}$

What is more, EPR is an application of the polluter pays principle (PPP), which also provides a potentially powerful tool to regulate the division of responsibilities for waste management among involved stakeholders and to influence the decisionmaking of producers. ${ }^{14}$ In the same vein, the implementation of the EPR policy within the polluter pays principle framework implies that producers are considered responsible for the environmental impacts of their products during their whole life cycle, including end-of-life management. ${ }^{15}$ Hence, if producers are responsible and legally liable to take back and recycle products, they will try to minimise the true costs of the environmental consequences of their products. Within the EPR context,

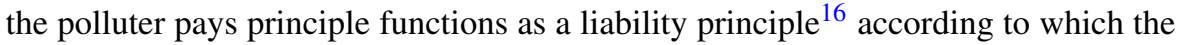

${ }^{10}$ Jans H. Jan, Vedder H.B.H. [6], pp. 480-481.

${ }^{11}$ Thieffry P., [12], pp. 157-158.

${ }^{12}$ European Commission, [2], p. 86.

${ }^{13}$ The Waste Framework Directive covers both quantitative and qualitative waste prevention and defines waste prevention as "measures taken before a substance, material or a product has become waste and that reduce: (a) the quantity of waste, including through the reuse of products or the extension of the life span of products; (b) the adverse impacts of the generated waste on the environment and human health; or (c) the content of harmful substances in materials and products" (See Art. 3(12) and Art. 9 of the Waste Framework Directive).

${ }^{14}$ Art. 15 Waste Framework Directive.

${ }^{15}$ European Commission, [2], p. 124.

${ }^{16}$ According to the approach adopted both at EU environmental legislation (i.e., Directive 2004/35/EC) and the case law of the European Cour, the polluter pays principle constitutes an environmental cost allocation 
identification of the 'polluter' and the allocation of liability is not based on "fault", but rather on the search for the "cheapest cost-avoider", namely the subject within the entire supply chain who can most effectively provide a remedy, or the "best briber" who can most effectively transmit the stimulus of the policy to the most appropriate stages. ${ }^{17}$ Thus, producers are the economic agents who can play a decisive role in avoiding and controlling the harmful environmental consequences of their products.

\subsection{EPR objectives and policy instruments}

As mentioned briefly in the introduction, the main EPR aims are the following: (1) to cover the products' end-of-life costs; (2) to provide eco-design incentives; (3) to achieve resource efficiency; and (4) to ensure the high quality of recycling. More specifically, EPR schemes endeavour to activate to some extent all involved stakeholders through the whole product life cycle, i.e., producers/distributors, Producer Responsibility Organisations (PROs), national authorities, consumers/citizens, local authorities, waste management operators and the recycling industry, in order to achieve effective collection and high level of re-utilisation of products and materials, environmentally sound waste treatment and the development of markets in secondary raw materials.

In this context, EPR is considered to be a policy principle. It is not in itself a legal mechanism or tool, but must be implemented via a toolbox of administrative, economic and informative mechanisms. According to the categorisation by the OECD ${ }^{18}$ four broad categories of EPR instruments exist:

- product take-back requirements which commonly involve establishing either mandatory or voluntary collection targets for specific products and materials, and assigning responsibility to producers or retailers for end-of-life management in order to achieve these targets. ${ }^{19}$ These requirements are normally accompanied by re-use, recycling and recovery targets to ensure that a minimum level of reutilisation of materials in products and packaging takes place;

- economic and market-based instruments which provide a financial incentive to producers to implement the EPR policy by mean of several forms, including deposit refund systems (DRS) and advance disposal fees (ADF), which are fees levied on individual products at the point of purchase, based on the estimated costs of collection and treatment, and intended to be used to finance end-of-life management of the products in question. ${ }^{20}$ As regards deposit refund systems, the main structure is that an initial payment (deposit) is made at purchase and is fully or partially refunded when the product is returned to a specific location (point of sale or at

principle aiming at fair and proportionate distribution of these costs among potential polluters based on a causal link between their contribution to the polluting event and the pollution as such.

${ }^{17}$ Massarutto A., [7], p. 15.

${ }^{18}$ OECD, [8], pp. 21-22.

${ }^{19}$ Watkins E., Gionfra S., Schweitzer J.-P., Pantzar M., Janssens C. and ten Brink P., [13], p. 10.

${ }^{20}$ Watkins E., Gionfra S., Schweitzer J.-P., Pantzar M., Janssens C. and ten Brink P., [13], p. 11 and OECD, [8], pp. 22-23. 
specified waste management sites). ${ }^{21}$ In Europe, deposit refund systems are most commonly used for metal and plastic beverage containers; ${ }^{22}$

- regulations and performance standards including technical standards and mandatory recycling rates; and

- information-based instruments which aim to indirectly support EPR programmes by raising public awareness via reporting requirements, labelling of products and information campaigns for consumers about producer responsibility and waste separation.

The aforementioned EPR mechanisms do not exist in isolation and are often complementary to other policy instruments such as pay-as-you-throw schemes, landfill and packaging taxes, product standards and regulations setting bans or binding targets, green public procurement (GPP) and voluntary agreements. ${ }^{23}$

\section{Legal and policy framework of EPR}

The legislative framework for the development of EPR at European Union level is organised in a multilayered way. First and foremost, the Waste Framework Directive adopted in 2008 clarified that it is for Member States to "decide that the costs of waste management are to be borne partly or wholly by the producer of the product from which the waste came and that the distributors of such products may share these costs" (Art. 14(2)). In this context, they may take legislative or non-legislative measures to ensure that any natural or legal person who professionally develops, manufactures, possesses, treats, sells or imports products (defined as producer of the product) has extended producer responsibility. Such measures are likely to include an acceptance of returned products and of the waste that remains after those products have been used, as well as the subsequent management of the waste and financial responsibility for similar activities. They may also encompass the obligation to provide publicly-available information on the extent to which the product is re-usable and recyclable (Art. 8).

In addition to this, the EPR is enshrined in four sectoral waste directives: Directive 94/62/EC on packaging and packaging waste; Directive 2000/53/EC on endof-life vehicles; Directive 2012/19/EC on waste electrical and electronic equipment (WEEE) and Directive 2006/66 on batteries and accumulators. Directive 94/62/EC on packaging and packaging waste was the first instance of EPR, having been adopted even before that concept itself was coined. Namely, it considers the implementation of EPR measure "to promote the objectives" 24 it pursues, as it is set in Article 14.

\footnotetext{
${ }^{21}$ OECD, [8], p. 22.

${ }^{22}$ Watkins E., Gionfra S., Schweitzer J.-P., Pantzar M., Janssens C. and ten Brink P., [13], p. 11.

${ }^{23}$ Watkins E., Gionfra S., Schweitzer J.-P., Pantzar M., Janssens C. and ten Brink P., [13], p. 17.

${ }^{24}$ Both minimal and maximal recovery and recycling targets are set by the Directive for packaging and packaging waste in order to avoid any possible resulting disturbance to the internal market and competition. Moreover, the Directive provides for maximum concentration levels in lead, cadmium, mercury and hexavalent chromium present in packaging as well as for essential requirements in order for packaging to be placed on the market (Articles 11 and 9).
} 
However, Member States are given a margin of discretion to adopt such measures as they deem appropriate "to ensure that systems are set up" to provide for the return and/or collection of used packaging and/or packaging waste from the consumers or any other final users as well as their reuse or recovery (Article 7.1).

Directive 2000/53/EC on end-of-life vehicles (ELVs) focuses mainly on the prevention of waste from used vehicles as well as on its recovery, and aims at the limitation of the use of hazardous substances in vehicles and the reduction of such use as soon as possible "so as in particular to prevent their release into the environment, make recycling easier and avoid the need to dispose of hazardous waste". ${ }^{25}$ In this context, the collection of end-of-life vehicles must be ensured by economic operators, which inter alia include for the purposes of the Directive producers, distributors as well as "other treatment operators of ELVs" (Art. 2.10). These economic operators must set up systems for the collection of all end-of-life vehicles, their transfer towards collection facilities adequately available within a Member State's territory and then to an authorised treatment facility (Art. 5). According to Article 5 of this Directive, the delivery of end-of-life vehicles to such authorised facilities must occur without any cost for the last holder and/or owner and it is, therefore, for the producer to bear such costs or, alternatively, to take the end-of-life vehicles back directly. This was explicitly confirmed by Court of Justice case law, ${ }^{26}$ highlighting the fact that this would act as an incentive to producers to prevent or limit the production of waste as early as at the design phase or else to minimise the costs of reuse and recovery by improving the recyclability of their vehicles. ${ }^{27}$

The overarching aim of Directive 2012/19/EC on waste electrical and electronic equipment (WEEE) is to make the producers of electrical and electronic equipment (EEEs) put in place separate collection, treatment and recovery facilities for their end-of-life products (WEEEs). The need for prevention is addressed through design requirements, which facilitate reuse and treatment of waste electrical and electronic equipment. Influenced by national protectionist considerations, the notion of the producer for the purposes of this Directive can be defined as a person who manufactures a product, or has such a product designed or manufactured and marketed under his name or trademark, but only if such a person performs these acts within the territory of the Member State where he/she/it is established. ${ }^{28}$ In addition to this, the notion of the producer also includes whoever "sells EEEs by means of distance communication directly to private households or to users other than private households in a Member State, and is established in another Member State or in a third country (Art. 3(f))". Member States must encourage the design and production of electrical and electronic equipment in such a way as to facilitate reuse, dismantling and recovery by taking appropriate measures so that producers implement specific design features and manufacturing processes and, therefore, do prevent waste electrical and electronic equipment from being reused (Art. 4).

As regards waste electrical and electronic equipment from private households, producers -individually or by joining a collective system-must provide at least for the

\footnotetext{
${ }^{25}$ Thieffry P., [12], p. 178.

${ }^{26}$ Case C-64/09 European Commission v French Republic, ECLI:EU:C:2010:197.

${ }^{27}$ Jans H. Jan, Vedder H.B.H. [6], p. 487.

${ }^{28}$ Thieffry P. [12], p. 179.
} 
financing of the collection, treatment, recovery and environmentally-sound disposal of such waste provided that it has been deposited at designated collection facilities, whether these be municipal or set up by producers (Art. 12(3)). In the case of "historic waste", ${ }^{29}$ the costs are required to be borne by one or several management systems to which all producers that exist on the market when the respective costs occur, contribute proportionally (Art. 12.4). Last but not least, the costs of appropriate analyses and inspections of used electrical and electronic equipment suspected to be waste electrical and electronic equipment may be charged to the producers, to third parties acting on their behalf or to other persons arranging for the shipment of the aforementioned electrical and electronic equipment (Art. 23.3).

Finally, Directive 2006/66 on batteries and accumulators aims, firstly, at minimising the negative impact of these and their waste as well as at harmonising the requirements concerning the heavy metal content and labelling of batteries and accumulators (see the Preamble, and recital No 1). Article 10 of the Directive sets minimal separate collection rates, calling for Member States to ensure that appropriate collection schemes are put in place for waste portable batteries and accumulators which enable end-users to discard them at "an accessible collection point in their vicinity, having regard to population density" at no cost and without an obligation to purchase a new battery or accumulator (Art. 8.1). Moreover, producers or third parties should set up schemes using best available techniques (BAT) to provide for the treatment and recycling of such end-of-life products (Art. 13.4), while the cost of collection, treatment and recycling of all waste portable batteries should be borne by the producers of batteries and accumulators (Art. 16.1), i.e., the person who places them for the first time within the territory of the Member States and who is involved on a professional basis, including by incorporating them into appliances and vehicles (Art. 3.12). However, in the light of technical progress and the practical experience which has been gained, it can be concluded that current minimum collection targets for waste portable batteries and minimum recycling requirements are not appropriate..$^{30}$

\section{Key features of existing EPR schemes}

\subsection{Individual vs. collective producer responsibility schemes}

An EPR system or scheme is defined as "any system set up by one or several producers to implement the EPR principle. It can be an individual system when a producer organises its own system (Individual Producer Responsibility-IPR), or a collective system (Collective Producer Responsibility-CPR) when several producers decide to

\footnotetext{
${ }^{29}$ WEEE from products placed on the market on or before 13 August 2005.

${ }^{30}$ Report from the Commission to the European Parliament, the Council, the European Economic and Social Committee and the Committee of the regions on the implementation and the impact on the environment and the functioning of the internal market of Directive 2066/66/EC of the European Parliament and of the Council of 6 September 2006 on batteries and accumulators and waste batteries and accumulators repealing Directive 91/157/EEC, COM(2019) 166 final, Brussels, 9.4.2019.
} 
collaborate and thus transfer their responsibility to a specific organisation (a Producer Responsibility Organisation (PRO))". ${ }^{31}$ A Producer Responsibility Organisation is an entity set up in collective EPR schemes in order to put into effect the EPR principle in the name of adhering companies through financing the collection and treatment of targeted waste, organising and supervising these activities and managing the corresponding data. ${ }^{32}$ Examples are the Duales System Deutschland in Germany and Eco-Emballages in France. ${ }^{33}$

Regarding the development of Producer Responsibility Organisations, what should be considered in particular is that mutualising the responsibilities of many different individual producers may lead to a risk of "averaging" the costs among producers and thereby deter individual efforts to secure compliance and enforcement and have less impact on enhancing eco-design. ${ }^{34}$ Moreover, it needs to be ensured that Producer Responsibility Organisations do not abuse market power through excessive or opaque pricing or other anti-competitive practices, such as horizontal agreements among competing producers to establish one or more Producer Responsibility Organisations, regulatory barriers to entering markets served by Producer Responsibility Organisations or vertical agreements between Producer Responsibility Organisations. $^{35}$

\subsection{Type of responsibility}

Insofar as concerns the typology of producer responsibility, there are two main approaches: mere (simple) financial responsibility and partial or full operational responsibility. ${ }^{36}$ More specifically, in simple financial EPR schemes, the responsibility of waste management is left to municipalities and producers take over the financial responsibility. In cases where the EPR schemes cover financial responsibility and partial operational responsibility, some organisational activities are kept under the responsibility of municipalities, whereas some other activities are under the responsibility of producers. Finally, in cases where producers fully take over both the financial and operational responsibility, they subcontract activities to professional waste collection and treatment operations or even own part of the collection and treatment infrastructure themselves. The main advantage of full operational responsibility consists of the responsible producer's direct monitoring of waste handling operations, whereas the key positive feature of simple financial responsibility refers to the fact that the waste management operations fall within the public service dimension responsibilities of local authorities for a sound and clean environment. ${ }^{37}$

\footnotetext{
${ }^{31}$ European Commission, [2], p. 2; OECD, [8], pp 28 and 70-78.

${ }^{32}$ European Commission, [2], p. 29.

${ }^{33}$ Further information on the role and the legal status of PROs, OECD, [8], p. 76-78.

${ }^{34}$ OECD, [10], p. 10.

${ }^{35}$ OECD, [8], pp. 46-48.

${ }^{36}$ Watkins E., Gionfra S., Schweitzer J.-P., Pantzar M., Janssens C. and ten Brink P., [13], p. 11.

${ }^{37}$ European Commission, [1], p. 87.
} 


\subsection{Cost coverage}

EPR schemes should cover the total costs associated with end-of-life products. Hence, they should, at least, cover the costs of separate collection, sorting and treatment operations, including the disposal of waste, litter cleaning and transport of waste, particularly in the case of remote or isolated areas. ${ }^{38}$ Moreover, they should cover costs related to waste prevention actions, public information and awareness raising as well as enforcement and surveillance of EPR systems. ${ }^{39}$

The overarching principle applied is the True Cost Principle which refers to the idea that the fee which is paid by each producer should reflect as faithfully as possible the end-of-life cost of his own products. ${ }^{40}$ In this way, EPR schemes tackle "free riding" and limit the number of producers who benefit from EPR systems without contributing their share of the costs. Specific provisions at European Union level need to be introduced regarding the total or partial coverage of costs of non-separately collected waste and littering, given that the non-internalisation of these costs equals to de facto subsidisation of waste production by the public budget. ${ }^{41}$

\section{Assessment of the existing EPR schemes}

\subsection{Successes of EPR schemes}

EPR schemes are associated with a range of benefits which contribute to moving towards more sustainable production and consumption. ${ }^{42}$ The following can be mentioned briefly:

(1) the creation of more and more efficient separate collection schemes for specific waste streams, which contributes to reduced disposal and increased recycling rates for the materials concerned; ${ }^{43}$

(2) the minimisation of the burden on public budgets which diminishes the financial cost of municipal waste management, by shifting financial responsibility for the end-of-life/waste phase of products from local municipalities and public authorities to producers;

(3) the generation of separated, high-quality waste materials which can be more readily processed into raw materials, thereby supporting the development of markets for secondary raw materials; ${ }^{44}$

(4) the incitement of producers to move towards eco-design innovations in order to reduce waste management costs; ${ }^{45}$ and

\footnotetext{
${ }^{38}$ ZeroWaste Europe, [14], p. 2.

${ }^{39}$ European Commission, [2], p. 89.

${ }^{40}$ European Commission, [2], p. 96.

${ }^{41}$ ZeroWaste Europe, [15], p. 21.

${ }^{42}$ OECD, [10], pp. 8-9.

${ }^{43}$ Plastics Europe, Plastics-the facts 2016. An analysis of European plastics production, demand and waste data, 2016, pp. 26-27.

${ }^{44}$ Watkins E., Gionfra S., Schweitzer J.-P., Pantzar M., Janssens C. and ten Brink P., [13], p. 18.

${ }^{45}$ OECD [10], p. 9.
} 
(5) the promotion of technological and organisational progress as well as contributing to resource security by diversifying the sources of material supply. ${ }^{46}$

\subsection{Pitfalls of EPR schemes}

While European Union legislation provides the enabling framework, national legislation by Member States specifies the operational aspects and the technical details of EPR schemes. As a result, EPR policies have been developed and implemented in a very heterogeneous way across the European Union. (In a comparable approach, Canada adopted a national action plan for EPR in 2009 which set a harmonised, outcome-driven model that has mostly resulted in systems where the producers discharge their responsibilities collectively with oversight by provincial governments. ${ }^{47}$ ) Assessing the performance and effectiveness of EPR models is thus a rather challenging and complex process, given the fragmentation at domestic level as well as the heterogeneous nature of the different waste streams. Furthermore, costs and performance are influenced by other factors external to the design and implementation of EPR schemes, such as population density, the value of secondary materials, the level of citizens' awareness, the standard of waste collection and treatment infrastructure, as well as the existence of other waste policies in force. ${ }^{48}$

In this context, the main weaknesses in the implementation of existing EPR schemes can be summarised as follows:

(1) the lack of a harmonised definition and scope for EPR; ${ }^{49}$

(2) the absence of transparent information, as well as fragmentation, regarding cost coverage ${ }^{50}$

(3) the limited influence of EPR schemes on eco-design improvements/promotion (namely, in the field of packaging waste, the current experiences of EPR implementation in different European Union Member States having shown that the measures applied have not succeeded in motivating packaging producers to turn to eco- and circular design) ${ }^{51}$

(4) the inadequacy of control/monitoring mechanisms;

(5) the failure to accurately determine the amount of costs which should be internalised through recycling targets, even though they are regarded as common performance indicators for EPR policies. Thus, separate collection targets should also be considered as EPR schemes covering separate collection and treatment costs, but not mixed waste collection $;^{52}$ and

(6) the lack of compliance and poor enforcement of the stakeholders involved due to Collective Producer Responsibility schemes.

\footnotetext{
${ }^{46}$ Ibid, p. 9.

${ }^{47}$ OECD, [8], p. 25-26.

${ }^{48}$ European Commission, [2], p. 76.

${ }^{49}$ Watkins E., Gionfra S., Schweitzer J.-P., Pantzar M., Janssens C. and ten Brink P., [13], pp. 19-21.

${ }^{50}$ OECD, [10], p. 11-14.

${ }^{51}$ ZeroWaste Europe, [14], p. 2-3.

${ }^{52}$ Ibid., p. 3.
} 


\section{Reconsidering EPR schemes in the light of the circular economy}

\subsection{The revised European Union waste legislation under the circular economy package}

The transition towards a circular economy at European Union level has put the spotlight on the need to treat waste as a resource with energy and materials embedded in products which must be kept in the economic process for as long as possible and at a high level of quality. ${ }^{53}$ According to the provisions of the Circular Economy Package, the main targets are the following:

- a target to recycle $65 \%$ of municipal waste by 2030 ;

- a target to recycle $75 \%$ of packaging waste by 2030 ;

- the use of economic incentives for producers to produce greener products and support recovery and recycling schemes;

- measures to promote re-use and to stimulate industrial symbiosis;

- a binding target to reduce landfill to a maximum of $10 \%$ of municipal waste by 2030;

- a ban on the landfilling of separately collected waste;

- the promotion of economic instruments to discourage landfilling; and

- simplified and improved definitions and harmonised methods to calculate recycling rates throughout the European Union.

Given that the development of EPR in Europe has already contributed to improvements in waste prevention, re-use and recycling, the new requirements under the Circular Economy for increasing both recycling and landfill reduction targets will provide a further incentive for better implementation of EPR schemes across the European Union. This is confirmed in the wake of the recent revision of the Waste Framework Directive, as Directive 2018/851/EU added to Article 8 the stipulation that "Member States may decide that producers of products that undertake financial or financial and organisational responsibilities for the management of the waste stage of a product's life cycle of their own accord should apply some or all of the general minimum requirements laid down in Article 8a", which seek to-inter alia-determine clear roles and responsibilities for all relevant actors involved, set waste treatment targets in line with the waste hierarchy, establish a reporting system, ensure equal treatment of producers, define geographical, product and material coverage, provide an appropriate availability of collection systems, and adopt the necessary financial and organisational means to do this. ${ }^{54}$

In addition to this, the amended Waste Framework Directive 2018/851 reiterated the strategic importance of waste prevention by confirming its place as a top priority for waste legislation according to the waste hierarchy. According to the revised Article 9, waste preventive measures taken by Member States shall

“(a) promote and support sustainable production and consumption models, (b) encourage the design, manufacturing and use of products that are resourceefficient, durable (including in terms of life span and absence of planned obsolescence), repairable, re-usable and upgradable, (d) encourage the re-use of

\footnotetext{
${ }^{53}$ ZeroWaste Europe, [15], p. 5.

${ }^{54}$ Par. 9 of Directive 2018/851/EU.
} 
products and the setting up of systems promoting repair and re-use activities, including in particular for electrical and electronic equipment, textiles and furniture, as well as packaging and construction materials and products, (f) reduce waste generation in processes related to industrial production, extraction of minerals, manufacturing, construction and demolition, taking into account best available techniques".

This more detailed and thorough formulation on waste prevention builds direct linkages to the EPR and highlights the need to reinforce its more effective implementation especially in the wake of the provisions requiring Member States to monitor and assess the implementation of the waste measures and the measures relating to re-use (paras. 4 and 5).

In this framework, EPR can contribute in different ways to the achievement of Circular Economy targets and objectives. In particular, EPR schemes will assist, by promoting the separate collection of waste, in meeting the municipal waste and packaging recycling targets, and through the avoidance of separately collected waste being sent to landfill and, therefore, encouraging producers to create more sustainable products. ${ }^{55}$ Furthermore, EPR may be a key instrument in promoting re-use, waste prevention and eco-design as well as industrial symbiosis by ensuring the provision of high quality secondary raw materials. ${ }^{56}$ In addition to this, Member States are encouraged via their EPR schemes to modulate fees for such schemes on the basis of durability, reparability, reusability and the presence of hazardous substances, and a database will be created containing information on hazardous substances in products ${ }^{57}$ in order to focus significantly more on qualitative prevention adopting substance restriction or bans on substances or materials that can cause negative environmental impacts when recovered, recycled or disposed. ${ }^{58}$

In this vein, EPR systems may cover landfill/disposal bans on products, minimum product standards, which include repairability, reusability, secondary raw material content and recyclability, as well as reporting requirements relating to both the number of products put on the market and the amount of waste products treated, re-used, recycled, recovered and sent to disposal. ${ }^{59}$ Under the Circular Economy, EPR should be a dynamic and evolving policy that needs to be continually reassessed so that it incorporates new incentive mechanisms for industries to permanently improve their products and processes. ${ }^{60}$

\subsection{The European Union plastic strategy}

Plastics are identified as one of the five priority areas in the European Union Action Plan for a circular economy together with food waste, critical raw materials, construction and demolition as well as biomass and bio-based products. According to the

\footnotetext{
${ }^{55}$ Watkins E., Gionfra S., Schweitzer J.-P., Pantzar M., Janssens C. and ten Brink P., [13], p. 28.

${ }^{56}$ Ibid., p. 28.

${ }^{57}$ European Environment Agency, [4], p. 31.

${ }^{58}$ ZeroWaste Europe, [15], p. 17.

${ }^{59}$ ZeroWaste Europe, [15], pp. 17-18.

${ }^{60}$ ZeroWaste Europe, [15], p. 15.
} 
Single Use Plastics Directive, plastic is defined as a material consisting of a polymer within the meaning of Article 3(5) of Regulation 1907/2006, to which additives or other substances may have been added, and which can function as a main structural component of final products, with the exception of natural polymers that have not been chemically modified. The durability of plastics is one of the key features of this material, which has made it both highly successful and environmentally damaging. ${ }^{61}$ EPR systems in this field have developed and expanded in response to the need to increase plastics circularity and to pursue global plastic waste objectives. ${ }^{62}$ However, at European level, low demand for recycled plastics, low commodity prices and uncertainties about market outlets has hindered the development of the European Union plastic recycling sector, which remains underdeveloped and fragmented. ${ }^{63}$ Recognising that currently in Europe only $30 \%$ of plastic waste is collected for recycling and that most recycling operations take place outside Europe, where environmental standards may be significantly lower, ${ }^{64}$ the European Commission took the initiative in this field, taking the view that plastics can make a major contribution towards a circular economy, helping to achieve a more resource-efficient and circular European recycling industry. 65

The European Union Plastic Strategy was published in 2018 with the aim of introducing a new vision reconsidering the way we produce, use and reprocess plastics; improving the design of plastics; and increasing their re-use and recycling - and therefore contributing to the circular transition by maintaining the value of plastics in the economy and minimising plastic waste generation. ${ }^{66}$ In this respect, the European Union plastic strategy seeks to address the planned targets through the plastics supply chain; improve the economics, quality and uptake of plastics recycling and re-use; reduce plastic leakage into the environment; and limit dependence on fossil-fuels as a raw material. ${ }^{67}$ The European Union Plastic Strategy contributes significantly to plastic waste prevention, given that a considerable percentage of plastics is not captured by an appropriate waste management system and degrades into micro-plastics that finally end up in marine or terrestrial ecosystems ${ }^{68}$ - on top of plastic waste which is collected and not recycled ending up in landfills and incinerators. Hence, in the context of a circular economy, the goal of plastic waste prevention is supported with specific measures and objectives targeting various aspects of plastic waste generation, such as reducing the consumption of plastic bags and reducing marine litter. In this vein and taking into account that the packaging industry meets the largest amount

${ }^{61}$ United Nations Environment Programme (UNEP), Marine Plastic Debris and Microplastics-Global lessons and research to inspire action and guide policy change, Nairobi, 2016a, p. 2 and 29.

62 ten Brink P., Schweitzer J.-P., Watkins E., Janssens C., de Smet M., Leslie H., [1], p. 4-6.

${ }^{63}$ Filho W.L., Saari U., Fedoruk M., Iital A., Moora H., Klöga M., Voronova V., [5], p. 551.

${ }^{64}$ European Environment Agency, [4], p. 15.

${ }^{65}$ Filho W.L., Saari U., Fedoruk M., Iital A., Moora H., Klöga M., Voronova V., [5], p. 551.

${ }^{66}$ Communication from the Commission to the European Parliament, the Council, the European Economic and Social Committee and the Committee of the regions, A European Strategy for plastics in a circular economy, COM/2018/028 final.

${ }^{67}$ Watkins E., Gionfra S., Schweitzer J.-P., Pantzar M., Janssens C. and ten Brink P., [13], p. 7.

${ }^{68}$ Filho W.L., Saari U., Fedoruk M., Iital A., Moora H., Klöga M., Voronova V., [5], p. 551. 
$(40 \%)$ of plastic material demand in the European Union, ${ }^{69}$ plastic packaging is particularly addressed in the Strategy by exploring ideas relating to EPR schemes, considerations about overpackaging, green public procurement, awareness campaigns and financial instruments that can help reduce packaging or replace single-use with reusable packaging. ${ }^{70}$

In addition to this, the Single Use Plastics Directive ${ }^{71}$ contains extensive elements concerning waste prevention, encouraging Member States to implement waste prevention measures - especially for single-use plastic items for which a more sustainable product alternative does not exist-such as providing information to consumers, using market-based instruments and establishing product design requirements. ${ }^{72}$ The European Union plastics strategy as well as the Single Use Plastics Directive both call for financial stimuli relating to more sustainable production and consumption patterns of plastic products. Thus, financial instruments, such as EPR schemes, play a crucial role in designing and enforcing waste policies which focus on the reduction of plastic consumption and the strengthening of waste prevention. However, the implementation of EPR schemes in plastic-containing waste streams in the European Union has manifested several problems and weaknesses. ${ }^{73}$

Therefore, the EPR framework needs to be re-evaluated and potentially redesigned. Emphasis should be given to the adoption of eco-modulation fees based on aspects related to the level of recyclability, the amount of recycled content of plastic packaging and the biodegradability and/or composability of the materials in question. ${ }^{74}$ Without a fee modulation that rewards those producers who take into account eco-design approaches in order to facilitate recycling and efforts to re-use, and to contribute to resource efficiency, there is no fair competition and EPR is not properly enforced. ${ }^{75}$ Moreover, in the light of increasing targets under the Circular Economy Package, there is a need to set higher separate collection and recycling targets for EPR systems bringing on board/activating involved stakeholders through the whole product life cycle: producers/distributors, Producer Responsibility Organisations (PROs), national authorities, consumers/citizens, local authorities, waste management operators and the recycling industry.

\section{Conclusion}

The need to unpack the EPR concept in the field of waste law and policy as well as reconsidering its implementation in the framework of the Circular Economy is

\footnotetext{
${ }^{69}$ PlasticsEurope, Plastics - the Facts 2018, An analysis of European plastics production, demand and waste data, 2018.

${ }^{70}$ European Environment Agency, [4], p. 11.

${ }^{71}$ Directive (EU) 2019/904 of the European Parliament and of the Council of 5 June 2019 on the reduction of the impact of certain plastic products on the environment.

${ }^{72}$ European Environment Agency, [4], p. 11.

${ }^{73}$ Filho W.L., Saari U., Fedoruk M., Iital A., Moora H., Klöga M., Voronova V., [5], p. 556.

${ }^{74}$ Watkins E., Gionfra S., Schweitzer J.-P., Pantzar M., Janssens C. and ten Brink P., [13], p. 2-3 and pp. 29-32 especially for plastic packaging.

${ }^{75}$ ZeroWaste Europe, [15], p. 22.
} 
still dogged by complexities and difficulties tracing the key discussions around the interface of waste and product law. Since EPR is a policy tool aiming at internalising end-of-life costs into producers' price and thereby creating an incentive for producers to take into account environmental aspects into the design of their products (i.e., waste prevention, lifetime, repairability, recyclability, hazardous substances content), it is clear that its implementation concerns both product and waste policy spheres closing the loops between waste management operations and product-oriented environmental policies.

This is in line with the overarching trend in the field of waste policy in moving towards an interface policy covering chemical, product and waste law. Indicative examples of these interconnections can be found in the Commission Communication on the options to address the interface between chemical, product and waste legislation $^{76}$ as well as on the Commission Staff working document on sustainable products in a circular economy- Towards a European Union Product Framework contributing to the Circular Economy'. ${ }^{77}$ Similar provisions confirming this interrelation can be found in the relevant pieces of legislation. Thus Article 11 of the Batteries and Accumulators Directive 91/157/EEC ${ }^{78}$ and Article 4 of the WEEE Directive ${ }^{79}$ constitute examples of design provisions within the waste legislation, whereas Article 18 of the revised Fertiliser Regulation explicitly lays down criteria according to which material constitutes waste in the context of a product legislation.

In this context, EPR may have a crucial role in tacking the current product design and waste management patterns which run counter the Circular Economy targets and priorities as well as in setting the framework for products which could be reused, repaired, rebuilt, refurbished, refinished, resold, recycled or composted. This transition hinges on some significant improvements or adjustments of the existing EPR schemes such as the following:

- seeking greater harmonisation of EPR schemes through European Union-wide definitions and criteria for EPR minimum requirements for product design relating to the material design and origin, as well as limits on additives/chemical substances that are problematic for product waste management and recycling; ${ }^{80}$

- enhancing the performance of existing EPR schemes by ensuring clear allocation of responsibilities among involved stakeholders, effective monitoring and enforcement mechanisms including the imposition of sanctions ${ }^{81}$ as well as full cost cov-

\footnotetext{
${ }^{76}$ Options to Address the Interface Between Chemical, Product and Waste Legislation, Communication from the Commission to the European Parliament, the Council, the European Economic and social Committee and the Committee of the regions on the implementation of the circular economy package Strasbourg, 16.1.2018, $\operatorname{COM(2018)~} 32$ final.

${ }^{77}$ Brussels, 4.3.2019, SWD(2019) 91 final (Commission staff working document on sustainable products in a circular economy).

78 'Member States shall ensure that manufacturers design appliances in such a way that waste batteries and accumulators can be readily removed $[\ldots]$ '.

79 'Member States shall, [... ], encourage cooperation between producers and recyclers and measures to promote design and production of EEE, notably in view of facilitating re-use, dismantling and recovery of WEEE, its components and materials [...]'.

${ }^{80}$ Filho W.L., Saari U., Fedoruk M., Iital A., Moora H., Klöga M., Voronova V., [5], p. 554.

${ }^{81}$ OECD, [8], p. 88 .
} 
erage of EPR schemes so that producers have the maximum possible incentive and the PPP is better applied;

- better supporting the integration of EPR schemes into European Union environmental and Circular Economy objectives; ${ }^{82}$

- boosting the effectiveness of EPR schemes in meeting reuse and recycling targets by coupling it with economic instruments such as landfill and incineration taxes, disposal bans for certain products or materials, packaging taxes and pay-as-youthrow systems.

- ensuring fair competition between EPR schemes on the national as well as the European Union level, and improved transparency regarding performance and costs/fees with an emphasis on preventing free-riding by producers, compliance by PROs with respect to managerial and fiduciary responsibilities and conformity with environmental and internal market regulations; ${ }^{83}$ and

- extending EPR schemes to additional types/application of plastics.

Acknowledgements Open Access funding provided by Projekt DEAL.

Publisher's Note Springer Nature remains neutral with regard to jurisdictional claims in published maps and institutional affiliations.

Open Access This article is licensed under a Creative Commons Attribution 4.0 International License, which permits use, sharing, adaptation, distribution and reproduction in any medium or format, as long as you give appropriate credit to the original author(s) and the source, provide a link to the Creative Commons licence, and indicate if changes were made. The images or other third party material in this article are included in the article's Creative Commons licence, unless indicated otherwise in a credit line to the material. If material is not included in the article's Creative Commons licence and your intended use is not permitted by statutory regulation or exceeds the permitted use, you will need to obtain permission directly from the copyright holder. To view a copy of this licence, visit http://creativecommons.org/licenses/by/4.0/.

\section{References}

1. ten Brink, P., Schweitzer, J.-P., Watkins, E., Janssens, C., de Smet, M., Leslie, H.: Circular economy measures to keep plastics and their value in the economy. Avoid waste and reduce marine litter. Economics Discussion Papers, No 2018-3, January 10 (2018)

2. European Commission-DG Environment: Development of Guidance on Extended Producer Responsibility (EPR). Final Report (2014)

3. European Commission: Being Wise with Waste: the EU's approach to waste management (2010)

4. European Environment Agency: Preventing plastic waste in Europe. EEA Report, No 02/2019

5. Filho, W.L., Saari, U., Fedoruk, M., Iital, A., Moora, H., Klöga, M., Voronova, V.: An overview of the problems posed by plastic products and the role of extended producer responsibility in Europe. J. Clean. Prod. 214, 550-558 (2019)

6. Jans, H.J., Vedder, H.B.H.: European Environmental Law-After Lisbon, 4th edn. (2012)

7. Massarutto, A.: The long and winding road to resource efficiency — an interdisciplinary perspective in extended producer responsibility. Resour. Conserv. Recycl. 85, 11-21 (2014)

8. OECD: Extended Producer Responsibility: Updated Guidance for Efficient Waste Management. OECD Publishing (2016)

9. OECD: Extended Producer Responsibility: A Guidance Manual for Governments. OECD Publishing (2001)

${ }^{82}$ Watkins E., Gionfra S., Schweitzer J.-P., Pantzar M., Janssens C. and ten Brink P., [13], p. 2.

${ }^{83}$ OECD, [8], p. 88. 
10. OECD: the State of play on Extended Producer Responsibility (EPR): Opportunities and Challenges. OECD Publishing (2014)

11. Steenmans, K., Malcolm, R., Marriott, J.: Commodification of waste: Legal and theoretical approaches to industrial symbiosis as part of a circular economy. University of Oslo Faculty of Law Research Paper No. 2017-26 (2017)

12. Thieffry, P.: Handbook of European Environmental Law. Bruylant, Brussels (2018)

13. Watkins, E., Gionfra, S., Schweitzer, J.-P., Pantzar, M., Janssens, C., ten Brink, P.: EPR in the EU Plastics Strategy and the Circular Economy: a focus on plastic packaging (2017)

14. ZeroWaste Europe: Extended Producer Responsibility-Creating the frame for circular products. Position Paper (2017)

15. ZeroWaste Europe: Redesigning Producer Responsibility—a new EPR is needed for a circular economy (2015) 